\title{
1. Financial globalization since the 1970s
}

Since the 1970s, the rapid expansion and globalization of financial markets shadows most other recent developments in international economics. This chapter documents and defines financial globalization and discusses what caused it: developments in information-processing technologies; government deregulation; and the more global nature of all economic activity. International interest rate and financial strategy 'parities' are presented as new, dominant, dynamic patterns in the global economy. Also in this chapter, it will be argued that financial market globalization has been a driving force behind recent imbalances in trade and investment between countries, and that the self-adjustment mechanisms within the global economy have been irreversibly changed by financial globalization.

An understanding of these recent structural changes provides a necessary introduction to subsequent chapters, where it will be argued that financial globalization processes are behind most of the major financial instabilities, trends, booms, and busts since the 1970s. In particular, what the author presents in Chapter 4 as 'the long boom' that extended from the early 1980s to its peak in 2006, as well as the recent global economic crisis that followed this boom, were both driven by financial globalization processes.

Richard O'Brien provides some helpful definitions of globalization processes, which can be applied to non-financial as well as financial markets:

International means activities taking place between nations ... multinational describes activities taking place in more than one nation ... global should refer to operations within an integral whole, if it is to have a separate meaning from the foregoing terms. Global combines the elements of international and multinational with a strong degree of integration between the different national parts ... A truly global service knows no internal boundaries, can be offered throughout the globe, and pays scant attention to national aspects. The nation becomes irrelevant, even though it will still exist. The closer we get to a global, integral whole, the closer we get to the end of geography. (O'Brien, 1992, p. 5)

For the purposes of this book, O'Brien's definition of globalism is useful-operations taking place within an integrated whole whereby 
geographic boundaries are not important. Given the dramatic financial opening of China, the Soviet Union, and others since the 1970s, the 'integrated whole' increasingly includes most developing as well as developed countries.

\section{THE RAPID EXPANSION OF INTERNATIONAL FINANCE, 1970-}

Beginning in the 1970s and continuing at least to a peak in 2006 of 'the long boom' that preceded the recent global crisis, there was a continuing rapid expansion of international financial activity. The London Eurodollar market, now the major market for the world's largest financial institutions, was in its infancy several decades ago - turnover in the entire year of 1970 was $\$ 59$ billion. But by the mid-1980s it was turning over $\$ 300$ billion of financial capital on an average working day. This volume was many times the total reserves of the world's central banks and at least 25 times the value of world trade in merchandise and services. The Euromarket for all currencies (in which securities issuers avoid home country regulations) grew to several trillion dollars of outstanding securities by the late 1990s (Federal Reserve Bank of Kansas City, 1997, p. 300).

From 1980 to 1985, global foreign exchange trading volume doubled to a level of $\$ 150$ billion per average working day, which was at least 12 times the value of world trade in merchandise and services. By 1990, the average volume of foreign exchange trading had reached $\$ 600$ billion per day ${ }^{1}$ and during the European currency crisis in late 1992, $\$ 1$ trillion per day. Since 1992, daily trading has averaged over $\$ 1$ trillion (Federal Reserve Bank of New York, 1995). Because each foreign exchange transaction involves two or more payments, it may be that $\$ 3.2$ trillion moves through the foreign exchange settlement systems each day. ${ }^{2}$

Virtually every type of international financial asset experienced a similar explosion in trading, especially in the 1980s or 1990s, and the list of such assets seems endless. Notably, the cross-border trading of corporate stock, which had increased from $\$ 100$ billion in 1980 to $\$ 800$ billion in 1986 , recovered from the world stock market crash of 1987 to reach $\$ 1.6$ trillion by 1990 (ibid.). Short-term commercial paper borrowing by corporations, often with bank guarantees, grew from $\$ 40$ billion in issues in 1970 to \$700 billion in 1997 (Federal Reserve Bank of Kansas City, 1997, pp. 263-4).

The US government securities market, with $\$ 3$ trillion of securities outstanding by the end of the 1980s and a daily turnover of more than $\$ 100$ billion, became the largest single-asset capital market in the world. The certification of foreign firms as primary dealers gave this market a boost in 
the 1980s. Primary dealers, the first-round traders with the Federal Reserve Bank, have an advantage because large institutional investors prefer doing business with primary dealers. Because the buying and selling of government securities by the Federal Reserve Bank is the main instrument of US monetary policy, foreign firms and their foreign clients began to play an active role in US monetary affairs. Up to 30 percent of new US government borrowings were supplied by foreign, especially Japanese, firms by the mid1980s. To downplay the significance of this, the Japanese securities firms were quick to point out that more than half of the clients for whom they traded US government securities were US citizens. ${ }^{3}$ Currently, in mid-2016, approximately $\$ 20$ trillion of US Treasury securities are outstanding, of which approximately $\$ 13.5$ trillion are marketable all over the world.

International financial transactions denominated in US dollars increased, until by the late 1980 s dollar holdings by foreign investors reached $\$ 1$ trillion, over 60 percent of which were in Japanese banks. To put this number into perspective, $\$ 1$ trillion was the annual amount being spent by the US federal government in the late 1980s, and equal to 20 percent of US annual gross domestic product (GDP).

The growth of 'offshore financial markets' since the 1970s as discussed below makes this type of data increasingly difficult to measure. But, it is likely that non-US-owned savings in dollars of almost $\$ 300$ billion per year were made available for new uses in the global economy in the late 1990s compared to less than $\$ 150$ billion per year in the early 1990 s. Sixty percent of the world's money supply in recent decades has been provided by the US dollar, and more dollars circulate outside the US than inside.

By the end of the 1980s, global financial markets were generating a net international flow of funds of more than $\$ 3$ trillion each month, that is, the flow of funds between countries which reconciles end of the month balance of payments data. The gross monthly flow was several orders of magnitude higher than this net flow, and it is increasingly impossible to measure given the often unregulated use of electronic funds transfers. Of the $\$ 3$ trillion net monthly flow by the end of the 1980 s, $\$ 2$ trillion was so-called stateless money, which is virtually exempt from the control of any government or official institution, but available for use by all countries. $^{4}$

Derivatives and other new exotic 'off-balance-sheet' contracts, which are based on underlying balance sheet assets such as stocks, bonds, and commodities, have also added to international finance. The Bank for International Settlements estimated that over-the-counter trading in derivatives, worldwide, was $\$ 1$ trillion in 1995, based upon outstanding contracts worth $\$ 40.7$ trillion. Outstanding contracts increased to $\$ 55$ trillion by the late 1990s, and regulatory authorities had not yet found a way to get 
companies to account for derivatives on their balance sheets. ${ }^{5}$ Also, daily turnover of exchange-listed (as opposed to over-the-counter) interest rate and futures derivatives contracts was even higher, based upon outstanding contracts worth \$16.6 trillion (Bank for International Settlements, 1995). Of course, the rise of subprime mortgage securities, collateralized debt obligations, and other more recent bundled securities played a key role in the 2007- global crisis, as discussed in Chapter 4.

Eurodollars (dollars held in accounts outside the US), and many of the other new money and financial accounts and forms that have been created since the 1970s, often do not have reserve requirements in the banking system; therefore quasi-money and loans can be created based upon these accounts almost without limit. The rise of 'offshore finance' has encouraged this process, because offshore accounts usually do not have reserve requirements. Offshore finance can be defined as 'markets where operators are permitted to raise funds from non-residents and invest or lend that money to non-residents free from regulations and taxes'. Once money is raised, then without a reserve requirement it can be loaned, deposited, re-loaned, re-deposited, re-loaned, and so on in offshore markets without limits imposed by the banking system.

Offshore markets are generally categorized into three types: 'spontaneous' offshore sites, as in the UK and Hong Kong; 'International Banking Facilities' (IBFs) as in New York and Tokyo; and 'tax havens' as in the Cayman Islands and Switzerland. London became an offshore site 'spontaneously' after the new Thatcher government abolished foreign currency exchange controls in 1979. In the UK, minimum reserve requirements were then abolished in August 1981 for onshore banks. The Bank of England wanted to maintain them, but the commercial banks lobbied successfully to abolish them so that they could compete in the Eurocurrency business with non-British institutions.

IBFs, which are more stringently licensed and controlled, were allowed in the US after 1980 in order to compete with London and the tax havens of the Caribbean. Tokyo followed suit with its IBF in 1984. All offshore sites can have tax advantages, but the typical tax haven is inhabited by 'letterbox' or 'brass plate' companies who exist mostly on paper, with the real activity taking place in 'proper onshore' financial centers. Tax havens struggle with respectability and anonymity in order to both attract deposits and avoid regulations. The Bahamas, for example, was identified by the International Monetary Fund (IMF) as the third largest international financial center in 1983 after Britain and the US, in terms of foreign liabilities, but after much publicity about drug trafficking and corruption it slipped to seventh place. The net worth of assets held in offshore markets has been difficult to estimate, but through the 1990s and until the start of 
the recent crisis as late as December 2008, it was estimated at \$6 trillion or approximately 20 percent of world GDP. ${ }^{6}$

Since the 1990s, according to some estimates, 'as much as half of the world's stock of money either resides in, or is passing through, tax havens' (Kochen, 1991, p. 73). According to IMF data, the Caymans and the Bahamas together held approximately $\$ 400$ billion in foreign liabilities in 1990 , which compared with $\$ 1,073$ billion in foreign liabilities held in the UK, \$659 held in Japan, and \$584 billion held in the US (of which the New York IBF held \$333 billion). Much of the money in tax havens is held by 'residents', and is therefore not included as part of foreign liabilities. The nine tax havens of the Caribbean have been home to half of the world's insurance companies and 15 percent of the world's merchant shipping companies. In addition, individual private savings of $\$ 500$ billion was held in tax havens in 1993 - an amount of money approximately equal to the entire savings of the world's 'super-rich' (Norton, 1993). Thus, Lord Rees-Mogg (1993) warned:

The world has never seen anything quite like this before. Governments are unlikely to recover their control of finance ... Any future attempts to restore capital controls or regain taxing power are quite implausible ... American and European welfare systems which depend on high tax may become insolvent. In the new world 'tax the rich' has ceased to be an option; the rich are not going to sit around waiting to be taxed.?

More recently, The Boston Consulting Group reckons that on paper roughly $\$ 8$ trillion of private financial wealth out of a global total of $\$ 123$ trillion sits offshore, but this excludes property, yachts and other fixed assets. And, over 30 percent of global foreign direct investment (FDI) is booked through havens. ${ }^{8}$ And, financial assets held in all of the world's 55-60 offshore banking sites could be as much as \$20 trillion. ${ }^{9}$

Since the 1990s, when international trade data is added up for all countries, world export revenues have fallen short of import expenditures by approximately $\$ 100$ billion per year. Economists agree that much of this $\$ 100$ billion represents a true shortfall (not just measurement error) of money which is not repatriated but instead is added to offshore finance. When combined with other flows that add to the stock of money in offshore markets, it may be that offshore markets are directing as much money as onshore markets.

Through the mid-1990s, approximately 60 percent of the world's official money reserves was held in US dollars, 20 percent in German marks, and 10 percent in Japanese yen. This dominance of the dollar, and this 90 percent dominance of the 'big three' did not change much after the euro replaced the mark and other European currencies at the end of the 1990s. 
Table 1.1 Sources and uses of foreign savings in dollars (\$billion)

\begin{tabular}{|c|c|c|c|c|c|}
\hline & 1992 & 1993 & 1994 & 1995 & 1996 \\
\hline \multicolumn{6}{|l|}{ Sources } \\
\hline Accumulating in offshore financial markets & 45 & 50 & 55 & 65 & 75 \\
\hline Non-US purchases of dollar bonds and notes & 10 & 20 & 25 & 30 & 45 \\
\hline Capital flight & 35 & 40 & 50 & 55 & 40 \\
\hline Direct and equity investment in the US & 10 & 60 & 50 & 60 & 85 \\
\hline $\begin{array}{l}\text { Net flows out of the reserves of: } \\
\text { Industrial countries } 1\end{array}$ & 0 & 40 & 80 & 65 & 20 \\
\hline LDCs $^{2} \quad$ Fuel exporters & 0 & 0 & -20 & 10 & 5 \\
\hline Non-fuel exporters & 40 & 30 & 15 & 10 & 15 \\
\hline Total & 140 & 240 & 255 & 295 & 285 \\
\hline \multicolumn{6}{|l|}{ Uses } \\
\hline $\begin{array}{l}\text { Net financing in dollars by: } \\
\text { Industrial countries (ex-US) }\end{array}$ & -35 & -100 & -20 & -20 & -25 \\
\hline \multirow[t]{2}{*}{ LDCs } & 10 & 20 & 25 & 25 & 15 \\
\hline & 35 & 55 & 30 & 50 & 50 \\
\hline US direct and portfolio investment abroad ${ }^{4}$ & 60 & 160 & 70 & 80 & 90 \\
\hline US current account deficit & 70 & 105 & 150 & 160 & 155 \\
\hline Total & 140 & 240 & 255 & 295 & 285 \\
\hline
\end{tabular}

Notes:

1. Additions to the US Treasury's holdings of foreign currency subtract from this total.

2. Less developed countries (LDCs).

3. Mexico is included under this heading.

4. US purchases of foreign currency bonds are added to this total.

Source: Brown (1996, p. 119).

In offshore financial markets, compared to the entire global economy, the US dollar has an unknown, but significantly larger share of the stock of money reserves. What has been possible to estimate is the yearly flow of foreign (non-US) savings of dollars. Table 1.1 shows a rare estimate of the annual sources and uses of US dollar financial flows outside the US, for 1992-96.

Table 1.1 estimates that, in the 1990s, there was a flow of more than $\$ 50$ billion dollars per year into offshore financial markets from international transactions wherein money was not repatriated (or measured) through official national balance of payments statistics. This flow is then a non-US source of dollars that can be used for just about anything in the global economy, and it is increasing. The same comments apply to the separate category of capital flight, which also adds approximately $\$ 50$ billion per year into the available supply of non-US-held dollars. 
By definition there is no firm data for capital flight, because it describes funds which leave a country in secret or disguised accounts to avoid taxes, political risks, inconvertibility risks, and so on. Other sources of non-USheld dollars, which are made available to the global economy each year, include dollars held in other countries which 'materialize' from private sources to buy dollar bonds, notes, direct and equity investments, and dollars which are 'freed-up' in other countries from official national reserve accounts. The grand total of non-US-held dollars, which were made available for use in the global financial markets each year, rose from an estimated \$140 billion in 1992 to almost \$300 billion in 1995 and 1996.

Because of the rise of offshore finance, perhaps a quarter of the world's money stock $(\mathrm{m})$ is not subject to significant reserve requirements. Thus, quasi-money, loans, and effective money flow can be created on the basis of a process of deposit lending and added to the world system almost without limit - the offshore financial markets can expand as long as the players remain profitable. Many of the players are limited by national regulations where they do other business, and they cannot expand offshore business beyond a certain share of onshore business. However, some players have no such regulations, and they are the modern-day equivalents of private goldsmiths in the European Renaissance. Dollar-credits today, just like gold-notes in the Renaissance, can be issued almost without limit, that is, as long as all private parties to the issuance profit from the use of those notes.

Central to this book, including explanations for the financial crises and recessions discussed in later chapters, is the existence and use of what the author would call this 'global money and credit pyramid', or what was called the 'global savings glut' by Federal Reserve Board Governor Ben Bernanke (Bernanke, 2005). As the volume and speed of international money and credit transfers increases, the risk of more dramatic boom, turning point, and bust stages of large-scale money-liquidity crises also increases.

\section{THE GLOBAL INFORMATION REVOLUTION AND GLOBAL FINANCE}

A financial transaction can loosely be defined as any business arrangement where money changes hands but the only other thing that changes hands is documentation. Both money and documentation are moved by information technologies; therefore financial market activity is enhanced by advances in those technologies. Expanding use and performance of electronic and regular mail service, telephones, computers, fax machines, 
image-processing devices, communication satellites, fiber optics, the internet, and so on creates better opportunities and more profits in financial services.

In fact, no sector of the global economy spends more on information technology than financial services: $\$ 500$ billion globally in 2009 , compared to (in descending order) $\$ 433$ billion spent on information technology by the global manufacturing sector, $\$ 390$ billion spent by governments, $\$ 211$ billion spent by retail and wholesale trade, \$202 billion spent by communications companies, and so on. ${ }^{10}$

The explosion of information technologies in recent decades did parallel the explosion of international finance as discussed in the previous section. For example, in 1946 the world had only one widely recognized computer, the ENIAC, built at the University of Pennsylvania, weighing 30 tons, utilizing 18,000 vacuum tubes, standing two stories high, covering 15,000 square feet, and costing several million dollars. In 1956, there were 600 computers in the US, in 1968, 30,000, in 1976, half a million, in 1988, several million, and by the end of the century half of all the households in the US had a free-standing computer.

Transistors were invented at Bell Laboratories in 1947 and integrated circuits - the ability to put large numbers of transistors on one silicon chip - were developed in the late 1950s. But by the late 1980s one memory chip could hold as many as one million bits of information. Computer technology benefited from the convergence of three breakthroughs: artificial intelligence, whereby computers solve problems by manipulating symbols and decision rules, making inferences and other probability decisions, and generally simulating human methods of intelligence; silicon compilers, which allow the complete design of integrated computer circuits on a computer by any computer-literate person with a $\$ 50,000$ work station; and massively parallel processing, whereby many computer operations occur simultaneously. Carver Mead of the California Institute of Technology, one of the industry experts and the inventor of the silicon compiler, estimated that these and other developments resulted in a 10,000-fold increase in the cost-effectiveness of information-based computer technology over the last two decades of the twentieth century. ${ }^{11}$

Other major scientific developments that fueled the information revolution were the development of fiber optic cables, a few pounds of which can now carry as much information as a ton of copper cables; and continuing development and deployment of communication satellites, which bounce information around the world at nearly the speed of light. A single communication satellite now displaces many tons of copper wire, and this displacement factor is increasing. By the mid-1980s approximately 60 percent of the trans-Pacific foreign currency trading and 50 percent 
of the trans-Atlantic foreign currency trading were done via satellite transmissions, ${ }^{12}$ which allowed for a greatly increased global flow of funds.

In the late 1980s, the telecommunications industry became the largest source of new jobs in the US and perhaps the world. Although the jobs were so scattered among equipment manufacturers, installers, and users that they were hard to keep track of, it was estimated in 1986 that more than 2 million were employed in this industry in the US, and the number was growing by 200,000 each year. ${ }^{13}$ In the US fewer letters were written in the 1980s, but there were more telephone calls - an average of four calls per day per person. More calls were made through computer modems to retrieve information from databases. In 1980, very few US homes had modems, but by the late 1980 s close to one million homes had them. ${ }^{14}$ This technology and others, including the facsimile (fax) machine, enhanced the efficiency of legal and business documentation. First generation fax machines from the 1970s took six minutes to send one page of documentation, but by the late 1980s the transmission time was down to three seconds and the popularity boomed. In 1987, 460,000 facsimile machines were installed in the US, compared to 190,000 in $1986 .{ }^{15}$ By the early $1990 \mathrm{~s}$, there were over one million installations per year. By the late 1980s, more than $\$ 100$ million worth of video teleconferencing services and equipment were sold in the US each year, and prices were declining by an average of 15 percent per year. Many corporations began using full-motion images, such as those of a sporting event, in their teleconferences. To handle all of this growth in the late 1980s, the capacity of international data circuits had to rise by 40 percent per year. ${ }^{16}$

By the year 2000, private bank telecommunications networks included Manufacturers Hanover Trust's T1 (high-speed) backbone network between its US locations which linked with its global X.25 packet-switching network based on Telnet (now Sprint) hardware and software that connects 52 cities in 27 foreign countries. In the 1980s, Citibank developed 100 separate private networks covering 92 countries, which were combined into an integrated global information network (GIN) in 1992. Chase has a similar network provided by Tymnet, which is owned by British Telecom, and Bank of America has a similar network to support its World Banking Division. Bankers Trust (purchased by Deutsche Bank in 1998) is noted for preferring earth-based to satellite links in its system in order to avoid several-second delays. In Europe, the Belgian-based Society for Worldwide Interbank Financial Telecommunications (SWIFT) was handling message volumes that rose from 3.2 million in 1977 to 604 million in 1995.

Changes in communications have always affected the structure of finance, but these developments of the last few decades were responsible for the truly global nature of today's financial markets. As participants 
used these new technologies and networks, linkages were formed between various national and international sub-economy financial markets. New international opportunities have occurred for centuries, but only recently has inter-dependence become so pervasive to merit the word 'global'. The transatlantic cable was completed way back in 1867, and the price of the dollar in London could then be found out in two minutes rather than two weeks. Even further back in the history of information finance, the Rothschilds used carrier pigeons to gain advance (and therefore profitable) news of the Napoleonic wars. Perhaps no single example of new international financial technology in the last few decades is more important than these, but thousands of lesser examples have been collectively more important in the globalization process.

The switching of financial markets from paper-driven trading floors to computer screens, as with America's NASDAQ and its hookups with London's 'off-(the London Stock) exchange market', is one example of how a new computer-based technology encouraged global trading. It was estimated that between $\$ 200$ million and $\$ 300$ million of foreign stock shares changed hands daily in London's off-exchange market in the UK's 'Big Bang' deregulation year of 1986, roughly double the levels of 1981, with half of that volume in US stocks. ${ }^{17}$ That level equaled as much as half the volume on the London Stock Exchange, which also trades many non-British securities.

By 2000, networks which handled staggering amounts of money included the Clearing House Interbank Payments System (CHIPS) run by private banks out of New York. CHIPS mostly handles foreign exchange and other large-value, wholesale-level international transactions, and the net settlement of its transactions is in dollar reserves through the Federal Reserve Bank of New York. Transfers through CHIPS increased from $\$ 16$ trillion in 1977 to more than $\$ 310$ trillion in 1997. The Federal Reserve's Fedwire is its electronic facility, which transfers reserve balances among private banks through dedicated wire and is the favored system for large domestic transfers. Transfers through Fedwire increased from \$2.6 trillion in 1977 to more than $\$ 225$ trillion in 1997. On a daily basis, CHIPS and Fedwire now move more than $\$ 2$ trillion. Retail systems such as credit and debit cards transfer an additional several hundred billion dollars per day. These daily recorded flows amount to half the entire broad money (m3) stock of the US, and more than one-third of the US gross domestic product for the whole year (Solomon, 1997, p. 7). Compared to the US, Europe uses even more electronic transfers; for example, its GIRO credit transfer system sends money directly from the buyer's account to the seller's and accounts for 19 percent of transactions, whereas indirect and debit-based checks account for only 2 percent. 
Countless other new technologies which enhanced the opportunities in boundary-less electronic finance include automatic transfer machines (ATMs), electronic points of sale, telephone banking, interactive screen communications between financial intermediaries and their wholesale and retail customers, ever more innovative debit and credit and smart cards, and even electronic wallets. Computer, telecommunications, and other 'non-bank' firms have begun to enter these markets. The Discover card was originally offered by the retailer Sears in the 1980s, and then sold to the brokerage firm Dean Witter. Shortly after, AT\&T's Universal credit card began offering Visa or MasterCard through Universal Bank. Globalization of plastic payment cards is now being realized. Worldwide spending at merchant locations on general-purpose cards totaled $\$ 1.47$ trillion in 1995 , and increased to $\$ 3.26$ trillion in 2000 and $\$ 6.43$ trillion in 2005 . Of the 1995 total, the US had a 47.5 percent share, Europe 25.8 percent, and Asia/Pacific 18.0 percent. ${ }^{18}$ Perhaps globalization of payment systems will move from plastic to the internet with alliances between companies like Microsoft and banks, as per Bill Gates' vision of 'frictionless capitalism' on the internet (Gates et al., 1995).

Most recently, 'blockchain' technology and 'distributed ledgers', which underpin the decentralized digital currency bitcoin, are being used as databases that are maintained collaboratively by all users, rather than by a single authority such as a bank. However, central banks are exploring the possibilities of virtual currency supported by these technologies, which could save on printing and administrative costs, be tougher to counterfeit, and be harder to use for illicit activity. ${ }^{19}$

Electronic banking programs have been used for as long as the internet has been popular-approximately three decades. The phrase that stuck was 'electronic funds transfer' (EFT), and EFT systems have allowed 'fast money' or 'hot money' flows, and now 'virtual money'. Virtual money is a catchphrase for a host of innovative payment forms such as electronic (e-) cash and digital money. As with internet communications, virtual money deliveries can be non-centralized and 'non-physical' beyond the $0-1$ on-off digital switching of computer systems.

Virtual money systems are not always subject to banking regulations. For example, in Hong Kong, by the end of the 1990s, the Octopus card system had created HK\$4 billion (\$516 million) of electronic money in an economy with approximately HK $\$ 100$ billion of currency and coins circulating. E-money transactions in the Octopus system amounted to HK $\$ 17$ billion per day. Octopus cards, owned by two-thirds of the local population, are easily read by sensors without waiting. The Octopus system is run as a joint venture by various transport companies, and is not 
technically a bank, but the companies are free to 'reuse' and invest most of the HK $\$ 4$ billion in customer deposits. Whether risk management and funds on hand are sufficient to cover reliably customer redemptions of the float is continually under review by the Hong Kong Monetary Authority.

What remains to be seen is the degree to which new virtual money systems create new money stock, versus the degree to which these systems merely move around 'real money' which already exists in bank accounts in deposit form. Chapter 2 develops this issue further, by relating the money stock and its velocity of circulation to the 'real' growth of financial and non-financial markets. Increasingly, it is difficult to know whether economy-wide growth in total transactions is being accommodated by increased money stock or increased velocity of circulation of money. Perhaps the distinction between money 'stock' and 'circulation of the stock' will become less useful as the monetary system co-evolves with new information-processing technologies.

More of the money stock moves as electromagnetic waves or photon particles. The average retail user of money still depends mostly on paper money and plastic cards, but the multinational corporation or financial institution or trader relies mostly on satellite and fiber optic routing. The large wholesale amounts are transferred electronically. In 1995 the US Federal Reserve estimated the value of US electronic transactions at $\$ 544$ trillion, check transactions at $\$ 73$ trillion, and currency and coin transactions at $\$ 2.2$ trillion; however, the physical number or volume of currency and coin transactions was estimated at 550 billion, check transactions at 62 billion, and electronic transactions at 19 billion.

\section{GOVERNMENTAL DEREGULATION AND INTERNATIONAL FINANCE}

The globalization of financial markets has also been encouraged by government deregulation. In the 1980s, especially, governments began abandoning financial market protectionism, deciding instead that the benefits provided to their citizens by the new international opportunities would outweigh any losses to previously protected groups.

Linked together with new information-processing technologies by the 1980s, borrowers and lenders were completing transactions in new international markets that were more profitable than any opportunities within the old domestic markets. Governments recognized the value of giving their citizens access to the new international markets, especially before other countries extended the same opportunities to their citizens. As with any profitable new markets, those who were able to participate first were often 
the most successful. Eventually, as competition increased, the profitability was reduced to more normal levels.

A threshold was reached by the early 1980s: governments began rushing toward financial market deregulation and internationalization in order to capture a large share of the new profitability for their own money centers, and in order to attract new international funds into their own economies. Policymakers removed ceilings on interest rates, reduced taxes and brokerage commissions on financial transactions, gave foreign financial firms greater access to the home financial markets, allowed increased privatization and securitization of assets, and took other steps which allowed money to move more freely and profitably between international and national markets.

Much of the global deregulation movement came from the Reagan/ Thatcher supply-side movement of the early 1980s in which the private markets were encouraged to take the lead - often without a clear understanding of what 'free markets' mean in international finance. Speaking to the author's class years later, the early 1980s US Comptroller of the Currency stated that he, Reagan, Federal Reserve Chairman Volcker, and others 'believed in the principle of free market finance, but we could not have possibly imagined the long run consequences'.

Deregulation was advanced under the consensus that financial market protectionism had failed. For example, The US Interest Equalization Tax of the 1960s was a form of protectionism; various US lenders were taxed for lending overseas, and immediately reduced their foreign activities and increased their domestic business. A long-run problem with protectionism, however, especially in financial markets, is that businesspeople usually find a way around the protectionism. The Interest Equalization Tax reduced taxable capital outflows from the US to negligible amounts in 1964, but non-taxable outflows rose to fill the gap by 1966. The tax encouraged the development of international financial markets, especially in Europe, that US banks could lend from, but which US policymakers could not regulate. New 'non-European' bond issues in Europe increased from less than $\$ 200$ million in 1962 to nearly $\$ 1.5$ billion in $1966 .{ }^{20}$ The Interest Equalization Tax was finally removed in 1974.

Other regulations that had shifted US bank activity to the Euromarkets were Regulation Q on interest rate ceilings, the Foreign Credit Restraint Program, and rules of the Office for Foreign Direct Investment. These types of regulations were dismantled in the 1980s.

On 1 April 1986, the US government ended the 5.5 percent interest rate ceiling on passbook accounts as the last stage in its deregulation of consumer interest rates paid by banks and savings and loan institutions. Especially important in this process had been the creation of automatic 
transfer services (ATS) in 1978, negotiable order of withdrawal (NOW) accounts in 1981, and Super NOW accounts in 1983. These are checkable 'money' accounts which, for the first time, offered interest rates high enough to attract funds which otherwise would be put into 'non-money' financial assets such as stocks, bonds, and money market funds (MMFs). By 1984, 8 percent of all checking accounts at US banks and 30 percent of all checking accounts at US thrifts were Super NOW accounts (Fortier and Phillis, 1985), which were able to pay interest rates almost as high as MMFs.

Also in 1986, three of Japan's biggest securities firms were allowed to become primary dealers in US government securities. Nomura and Daiwa Securities Companies were then able to trade directly with the New York Federal Reserve Bank as part of their battle for global markets. Additionally, the Industrial Bank of Japan gained this privilege via its purchase of primary dealer Aubrey G. Lanston \& Co. On that date five other foreign firms - one Canadian, one Australian, one from Hong Kong, and two British institutions - already owned primary dealers. ${ }^{21}$

The US Glass-Steagall laws of the 1930s, which separate commercial and investment banking, were also slowly dismantled in the 1980s and 1990s despite some attempts at re-regulation during each financial crisis. US banks could then trade stocks for their customers, but non-bank commercial enterprises could not generally own banks. Of course, since the 2007- financial crisis re-regulation has been significant, including conversion of all remaining investment banks in the US into bank holding companies (allowing greater Federal Reserve benefits and oversight), and some restoration and oversight of the lines between commercial and investment banking (i.e. the 2010 Dodd-Frank Wall Street Reform and Consumer Protection Act, and a new section 13 to the Bank Holding Company Act of 1956, which is commonly referred to as the new Volcker rule).

UK financial deregulation in the 1980s paralleled that in the US, and due to the international dominance of New York and London as financial centers, these two countries influenced financial developments elsewhere. In October 1979 the UK removed all inward and outward barriers to capital flows. Consequently, Britain experienced an annual portfolio investment outflow for the 1980-83 period that was 1,800 times higher than in the 1975-78 period (Taylor and Tonks, 1989).

Finally, on 26 October 1986 London's 'Big Bang' financial market deregulation scrapped 85 years of fixed commissions for brokers as well as separation of powers between brokers. As stated by John M. Hennessy, chairman of Crédit Suisse First Boston Ltd., a leading international investment bank based in London, 'Big Bang is an attempt to generate a few global competitors among the British institutions'. ${ }^{22}$ Competition 
increased immediately. Forty-nine firms, including American, European, and Far East financial giants, had signed up before 26 October to market British stocks and government bonds; only 19 companies had been doing this trading previously. ${ }^{23}$ In addition, after 26 October commissions charged by financial intermediaries dropped as much as 50 percent.

Recognizing the more integrated and global nature of their financial system, the European Community Commission began moving toward a unified financial services market for the 12 Common Market countries (by 1992), including uniform lending restrictions and reporting of large loans. ${ }^{24}$ Also, as of 1992 all international banks subject to the auspices of the Bank for International Settlements (most developed countries and in the future some LDCs) must meet common capital adequacy targets- the first real attempt at a global standard for banking.

Anxious not to lose business to New York and London, other countries embraced the international financial markets in the 1980s. On 4 December 1986, the Ontario, Canada, government announced that it would open the highly restricted Canadian securities industry to unrestricted access by foreigners and Canadian financial institutions. Previous law prohibited foreigners and Canadians outside the securities industry from owning more than 10 percent of a securities dealer. Under the new regulations, foreigners could own 50 percent of a Canadian securities dealer after 30 June 1987 and 100 percent after 30 June $1988 .^{25}$

By 1984, Japan had given US banks virtually free access to many of the Tokyo financial markets including the underwriting of Japanese government bonds. The Japanese government had decontrolled most national interest rates by the late 1980s, thus finishing a process started in 1979, when increased competition was created between Japanese banks, securities firms, and insurance companies. Notably, Japanese reform of the Foreign Exchange and Foreign Trade Control law in December 1980 allowed these companies greater ability to issue bonds, buy and sell securities, and hold foreign currency deposits. While the holding of foreign securities by Japanese insurance companies has been restricted, statutory limits have not been binding, and these insurance companies have increased their holdings. And, by the mid-1980s, US securities firms had become active players in the Tokyo market. Paine Webber opened a large Tokyo branch office in April 1986; Morgan Stanley \& Co. at that time had built a Tokyo staff of 160; Goldman, Sachs \& Co. had 60 people; Salomon Brothers had 80; and Merrill Lynch had 260. And, what has been called Japan's 'Big Bang' occurred in April 1998 when the Foreign Exchange Law abolished the remaining restrictions on international financial transactions.

Mr. Yusuke Kashiwagi, chairman of the Bank of Tokyo, correctly prophesied during an important lecture to the IMF in Washington in September 
1986, that Tokyo would be linked with New York and London to form a 'three-part axis of global finance'. ${ }^{26}$ Tokyo sits in a time zone between New York and London and it makes a natural bridge for 24-hour-a-day trading. Mr. Kashiwagi estimated that the American financial market had an annual volume of $\$ 7.1$ trillion in 1986, Japan was second in the world with $\$ 2.2$ trillion, and Great Britain was third at \$1.6 trillion. Between 1970 and 1985, Japan's financial markets grew at the rate of 18.3 percent per year, Great Britain's at 14.5 percent, and the US's at 8.8 percent. Integration between these markets has more recently made it difficult to estimate separate statistics. The US Federal Reserve Bank's funds transfer business day has been extended to now begin at 9:00 p.m. (Eastern time) on the preceding calendar day (rather than 8:30 a.m. on the calendar day of the transfer) and ends at 6.30 p.m. so that the system can receive and process foreign exchange transactions while both European and Asian markets are also open. Related initiatives by banks from most large industrial countries have also created limited-purpose banks to clear foreign exchange transactions and thus remove payment delays in CHIPS.

Germany's major deregulation was its liberalization of foreign exchange controls in March 1981. International capital movements were also encouraged when Germany abolished its withholding tax on interest payments to foreigners in August 1984 - one month after the US had removed its withholding tax, and during the same several months that Japan reciprocated.

The process of financial globalization was further encouraged in the 1980s where there was a need to reduce budget deficits, because governments now had a ready source of funds in the international privatization of their assets. For example, after Mitterrand's socialist revolution lost support in France and Chirac was elected Prime Minister in 1986, the center-right coalition embarked on an ambitious denationalization program to privatize ownership of many large companies. An unexpectedly popular $\$ 40$ billion sell-off of government corporations to the private sector seemed to mark the end of the socialist revolution. The denationalization program allowed foreign investors to buy up to 20 percent of the newly privatized firms. In October 1986, the British broker Morgan Grenfell Securities International placed a $\$ 100$ million package of French securities with US and British institutional investors, the biggest transaction of its kind in French history. ${ }^{27}$ By January 1990, France had completed its piecemeal liberalization of foreign capital flow regulations.

Even the historically closed China and USSR began developing links with global financial markets in the explosive mid-1980s. In November 1986, a group of top Wall Street executives met with high Chinese political and financial officials in Peking for talks on how securities markets should be run and on how financial capital can be raised. Stock trading in China 
began on 26 September 1986 for the first time since the Communists took power in 1949: the Jingan-district branch of Shanghai Trust \& Investment Co., China's main venue for stock trading, eventually had to move in December 1986 from a branch office measuring only 430 square feet to a new location five times as large. ${ }^{28}$

Besides beginning to trade local issues in securities markets, China also sold more than $\$ 2.5$ billion of debt securities on international markets in 1985 and 1986 and began developing a modern banking system. ${ }^{29}$ China's five-year plan for 1986-90 resulted in approximately \$30 billion in new foreign loans, which increased China's foreign debt from $\$ 14$ billion to $\$ 40$ billion over that period. China issued its first Eurodollar bonds in August 1987, two months after settling a 38-year dispute with the British government over defaulted bonds and British assets that were seized during the Communist uprising in 1949. ${ }^{30}$

Perhaps the most significant economic change in the USSR during the Gorbachev period was the increased access to Western financial markets. In 1987 the USSR settled czarist debts with Britain and Switzerland in order to gain access to the European bond markets. In 1988, the USSR had its first public bond offering on the international capital markets and owed \$25.9 billion to Western commercial banks compared to $\$ 11.3$ billion in $1985 .{ }^{31}$

In non-Soviet Eastern Europe, also like the USSR suffering economic decline in the 1980s in most regions, regulatory reforms and attempts to sustain economic growth in 1990 were defined largely by a new dependence on foreign debt. Western grants and low-cost credits of more than $\$ 1.5$ billion were provided for non-Soviet Eastern Europe in 1990, and additional, non-concessional Western bilateral and multilateral credits of $\$ 5.3$ billion were arranged for 1990-92 (Allen, 1991, p. 477). To raise funds, in the spring of 1990, Hungary, Poland, and Czechoslovakia began selling hundreds of state-owned enterprises to private international enterprises, and international joint business ventures in non-Soviet Eastern Europe increased dramatically after 1989 to a total, in 1990, of approximately 500 in Czechoslovakia and well over 1,000 in both Poland and Hungary. Approximately $\$ 100$ billion of business assets in non-Soviet Eastern Europe were identified for sale in the early 1990s, an amount approximately equal to the foreign debt of this region before the revolutions of 1989 and $1990 .^{32}$ 


\section{INTEREST RATE AND FINANCIAL STRATEGY PARITIES}

The globalization of financial markets has meant that borrowers, lenders, and other investors have increased ability to make inexpensive international contracts through financial intermediaries. Globalization is encouraged by the information revolution, which makes businesspeople and financial intermediaries more aware of, and networked to, all the international opportunities, so that the financial markets become more dynamic and price competitive. Dynamic means that the reactions of market participants are quickly provoked and accommodated. Price competitive means that no businessperson or financial intermediary has a strong pricing advantage over others for a significant period of time. For example, each must accept the interest rate for certain types of transactions that the global market produces.

Some efficiencies result from the dynamic, price-competitive nature of the globalized financial market. Financial intermediaries must adopt the cheapest information-based technologies that can reliably perform the necessary services if they are to profitably survive. Embracing the information revolution is crucial to them. Also, financial intermediaries must be well informed about the needs of their customers. If they do not supply the mix of financial services which their customers are most willing to pay for, then they will also be competed out of the global market.

With fewer restrictions on international financial transactions, interest rates - or more precisely the total expected return including foreign currency risk-for similar types of loans are more uniform around the globe, and these new global interest rates are lower than the average of all the old national interest rates. The new global interest rates are lower, because low interest rate lenders have dramatically expanded their international business outside domestic markets, which has also expanded international loan volumes. There has been a net expansion of the volume of loans because more people have borrowed at the lower global interest rates. The issuers of the low interest rate loans have profitably expanded to accommodate these new borrowers.

For example, the high interest rates in international markets in the early 1980s were in US dollars, and the low interest rates were in Japanese yen and German marks. Then, as financial markets were rapidly deregulated and integrated between 1983 and 1988, the dollar's share of international lending fell from 72 percent to 53 percent as US banks and thrifts were outcompeted, the yen's share increased from 3 percent to 10 percent, and the mark's share increased from 5 percent to 10 percent. ${ }^{33}$ In addition, the volume of international lending increased faster than at any time in 
modern history, as average interest rates in the global economy were cut in half. Also, interest rates in the major currencies moved closer together during this period. Long-term dollar interest rates adjusted for inflation had reached a peak of 10 percent in the middle of 1984, but then declined steadily to 3.5 percent at the end of 1986 . But the comparable yen and mark interest rates rose slightly over this period.

An important equilibrium position of globalized financial markets is called 'interest rate parity' (IRP). First, IRP requires that national and international interest rates for the same types of loans in the same currency have to be equal. Otherwise, arbitragers would simultaneously borrow in one market and lend in another and make tremendous profits, profits much greater than could ever be attained from merchandise and services trade. In the early 1980s, financial market arbitrage became much more profitable on the margin than merchandise and services trade. Therefore, the fully arbitraged IRP-seeking equilibrium position of financial markets became the driving force that merchandise and services trade conformed to. This dominance of IRP beginning in the 1980s differed from more traditional thinking whereby financial transactions were instead believed to accommodate merchandise and services trade.

Using the equality of national and international interest rates in the same currency as a measure of the globalization of national financial markets, it is clear that many types of financial transactions between the major industrial countries became fully globalized in the early 1980s. For example, between October 1983 and May 1984 the average differential between three-month Eurodollar interest rates and the corresponding rates in New York was only 0.1 percentage points. The same test comparing Deutsche mark interest rates in the Euromarket and German markets showed a differential of 0.04 percentage points. ${ }^{34}$

Frankel (1989) has shown that domestic versus international owncurrency interest rate differentials for Germany collapsed in 1974 when most capital inflow restrictions were removed. The differential for Italy and France collapsed in about mid-1986 when capital outflow restrictions were removed in those two countries and the European Monetary System (EMS) was realigned. Also, Artis and Taylor (1989) have shown that this differential tended toward zero in the UK after inward and outward capital controls were removed in October 1979.

Japan's case study also shows the relationship between financial market deregulation and globalization in the early 1980s. Between 1975 and 1979, before Japanese deregulation, the differential between three-month yen interest rates in the Eurocurrency and Japanese markets averaged a large 2.06 percentage points. The Japanese government began removing the restrictions on its financial markets in the early 1980s, and in 1984 
this interest rate differential had been reduced to 0.31 percentage points. Finally, in 1985, Japan's financial markets, with respect to these statistics, had become as globalized as those in the US, UK, and Germany - this yen interest rate differential had dropped to 0.05 percentage points (Artis and Taylor, 1989).

Second, IRP requires that the same types of loans, which have been insured against foreign currency risk, produce the same total return for the investor even though they are denominated in different currencies. Currency risk can be covered or hedged away via transactions in the forward-looking markets.

For example, suppose that dollar interest rates were currently 8 percent, euro interest rates were 13 percent, and the current spot market exchange rate was $\$ 1$ for 1.5 euros. Suppose also that one could agree today to swap $\$ 1$ for 1.57 euros one year from now. If an investor had his/her savings in dollars today but wanted his/her savings converted into euros one year from now, should he/she (a) convert on the spot market today at $\$ 1 / 1.5$ euros and begin earning 13 percent on his newly acquired euros; or (b) agree today to convert one year from now at the $\$ 1 / 1.57$ euros future rate and continue earning 8 percent on his dollars until that time; or (c) continue earning 8 percent on his dollars and convert them into euros one year from now at whatever the spot market exchange rate happened to be then?

Ignoring commissions and any other transactions costs, options (a) and (b) would produce the same euro savings one year from now with certainty. For example, savings of $\$ 100$ under option (a) would be converted into 150 euros today and earn $(150$ euros $\times 0.13)=19.5$ euros in interest for a total of 169.5 euros one year from now, and under option (b) savings of $\$ 100$ would earn interest of $(\$ 100 \times 0.08)=\$ 8$ for a total of $\$ 108$ one year from now which would then be converted with the futures contract at $\$ 1 / 1.57$ euros. The $\$ 108$ would thus be converted into $(108 \times 1.57)=169.5$ euros one year from now. (Note: these calculations are approximate, and exact equations are developed in textbooks.)

The risk-free equivalence of options (a) and (b) demonstrates the IRP equilibrium for different currencies, and it is summarized as follows: the current interest rate differential between currencies (in this case a 5 percent differential in favor of the euro) must be eliminated by the difference in the spot versus forward exchange rate (in this case the dollar carries a forward premium against the euro of approximately 5 percent from 1.5 to 1.57 ) to yield the same total return for options (a) and (b).

For the major currencies with well-developed, forward-looking market opportunities, such as those that are actively traded in the Eurocurrency markets, 100 percent of the deviations from (a) and (b) equivalence could be accounted for by commissions and other normal transactions costs by 
the late 1980s (Taylor, 1988), a result called 'covered interest parity'. When arbitrage eliminates differences in national versus Eurocurrency interest rates on the same currency, it also eliminates differences in the risk-free total return on different currencies. In the above example, money would be moved between dollar and euro loans until interest rates and/or forward versus spot exchange rate differentials adjusted to produce the equivalence. Non-equivalence could not be sustained because of the tremendous profit-seeking flows of capital that would exploit the inefficiency until equivalence was produced.

Option (c) in the above example would expose the investor to currency risk, unlike options (a) and (b), and therefore may or may not be used given his/her risk tolerance. If used, option (c) would result in a superior return to options (a) and (b) if the spot exchange rate for \$1 appreciates above 1.57 euros at year-end, and option (c) would produce a lower return if the dollar ended the year lower than 1.57 euros. In other words, whether or not the spot rate ends the forward-looking time period above or below today's risk-free forward rate will determine the benefit of speculating as per option (c) versus hedging as per options (a) and (b). Therefore, beliefs about future spot rates may also lead to tremendous profit-seeking flows of capital and realignment of interest rates and exchange rates until investors believe option (c) to be equally desirable to options (a) and (b).

If option (c) produces the same return as (a) and (b) the result is called uncovered interest parity. However, most research indicates that substantial errors in predicting future spot rates does not allow for uncovered interest parity (Frankel and Froot, 1989). In other words, the risk-free forward rate is not a good predictor of the future spot rate, and speculators must assume substantial risk when accepting option (c).

As currency exchange rates adjusted as part of the process whereby IRP was achieved in the 1980s, international currency-adjusted prices for merchandise were pushed substantially out of alignment, as discussed later in Section V of this chapter. Therefore, trade balances have fluctuated wildly as driven by these financial processes, and historic relationships between currency exchange rates and trade balances have no longer prevailed. Purchasing power parity (PPP), the theory that currency exchange rates move up or down to equate national and international prices of merchandise and services (and thus trade is always rebalanced), has become unreliable for forecasting purposes. For example, no longer does a country's currency necessarily increase in value if it has an export price advantage and is selling more merchandise and services to the rest of the world than vice versa. If an export-driven country is able to lower the interest rates on its currency, its currency could even depreciate due to a substantial outflow of investment funds to higher interest rate currencies. 
Table 1.2 Purchasing power parity exchange rate levels of one US dollar (versus actual exchange rates)

\begin{tabular}{lrrrr}
\hline & 1990 & 1993 & \multicolumn{1}{c}{1995} & \multicolumn{1}{c}{1997} \\
\hline Japan (yen) & $195(134)$ & $184(112)$ & $169(103)$ & $163(130)$ \\
Germany (mark) & $2.09(1.49)$ & $2.10(1.73)$ & $2.02(1.43)$ & $2.00(1.79)$ \\
\hline
\end{tabular}

Source: Organisation for Economic Co-operation and Development (OECD).

Table 1.2 shows just how much the exchange rate of the US dollar deviated in the 1990s from its PPP levels relative to the Japanese yen and the German mark. These PPP exchange rate levels equate the average prices of tradable merchandise and services between the US, Japan, and Germany. There was no stability or convergence of exchange rates to PPP levels. The yen and mark remained persistently overvalued against the dollar in the 1990s, yet the US current account balance first improved and then worsened (see Figure 2.6).

The IRP equilibrium discussed above equates the total expected return on different sources of international borrowing and lending. Money moves between the globalized countries and currencies until, on the margin, the market for borrowing and lending is efficient. Arbitragers are then indifferent between countries and currencies for their next transaction.

Borrowing and lending are associated with debtors and creditors - those who exchange bonds, commercial paper, certificates of deposit, and other fixed-income IOUs. It is for these types of financial transactions that IRP has been statistically verified. Total expected returns on these 'pure debt' instruments have indeed converged. However, IRP can be more generally understood as financial strategy parity (FSP). For those globalized countries and currencies subjected to IRP in the 1980s, a more general convergence of financial strategies also occurred as participants were presented with more similar opportunities in other, non-pure-debt markets. Specifically, corporations began choosing more similar debt versus equity financing strategies. Also, there was greater convergence of price to earnings ratios across increasingly internationalized stock markets. As arbitragers and other participants compared returns and risks on a more global spectrum of financial assets, the best common strategies were chosen.

\section{A. International Debt to Equity Ratios Converge}

Much of the increase in US corporate debt in the 1980s can be seen as a convergence toward desirable international debt to equity ratios. Before 
financial markets became rapidly globalized, that is between 1972 and 1982, the percentage of total debt in the capital stock (machines, factories, etc.) of Japanese and German manufacturers averaged 66 percent and 64 percent, respectively, more than twice the 30 percent of US manufacturers. ${ }^{35}$ Although popular sentiment disagreed, it is likely that this lower debt-position of US corporations at the time disadvantaged them relative to their Japanese and German competitors before 1982; and it is likely that the increase in US corporate debt after 1982 was a move in the right direction.

An argument defending the increase in US corporate debt after 1982 proceeds as follows: US managers, especially in the post-1982 period of 'nuclear finance', impatient owners, and hostile leveraged buyouts of companies, needed to insure high short-run returns on machines, factories, land, and so on that are owned outright (i.e. the equity or stock of the firm) in order to maintain high stock prices. High stock prices, prices that fully reflect the replacement value of the machines, factories, land, and so on, please the current owners and discourage hostile corporate 'raiders' from buying stock and gaining control of company assets. In other words, during the boom years for financial markets in the early and mid-1980s, it became popular to radically reorganize the ownership of business assets, and those assets had to be well-presented for marketability-high short-run returns and prices.

However, managers did not need to insure such high short-run returns on debt-capital, because it is not the equity of the firm, but of the lending institution. Debt-capital need only produce enough revenues over the long-run to justify the loan which financed it. Debt-capital was not so marketable or so subject to new ownership as equity-capital (at least in the 1980s), and thus debt-capital has been more insulated from disruptive reorganization by nuclear finance and corporate raiders. From 1972 through 1982, the average before-tax, gross return on capital for equity-biased US manufacturers was 21.1 percent, compared with 14.2 percent and 15.7 percent in debt-biased Japan and West Germany, respectively. ${ }^{36}$

Gross returns on capital should not be confused with corporate profitability for four reasons: (1) they are before-tax returns, and tax systems vary; (2) other non-capital expenses such as wages affect profitability; (3) the gross return on capital becomes institutionalized as a cost of capital, for example to the newer firms who must buy or lease it away from competing uses - in 1981 the cost of raising capital in the US was 16.6 percent, which compared unfavorably with 9 percent in Japan and West Germany; ${ }^{37}$ (4) the profitability or net return on a firm's capital operations should be measured as the difference between the gross returns and the costs of 
raising capital. This calculation indicates that profit rates on capital in Japan and West Germany were one to two percentage points higher than in the US before the rapid globalization period beginning in the early 1980s.

The capital cost disadvantage of US industry worsened in the early 1980s. Economists at Georgetown University concluded that in 1985 US industry spent 19 percent more than Japan to service its capital, that is, raise it, depreciate it, and pay taxes on it. Taxes were identified as the key reason, because Japan was found to tax its capital formation at a 37 percent lower rate than the US.

If the Japanese system [including higher debt, non-existent taxes before 1986 on the dividends and capital gains of individuals, etc.] were adopted in the US, the cost of US capital ... would fall by 16 percent. This is the equivalent to an increase in profit margins on output of 5 percentage points [about double our present rate] and is an amount larger than total US corporate income tax receipts. ${ }^{38}$

The lower US profit rates on machines and factories compared to Japan and Germany in the 1970s and early 1980s, due to higher taxes and less debt, meant that fewer corporate investment projects could be justified in the US compared to Japan and Germany. Especially hard hit in the US were investments in product innovation and the opening of new industries and markets. These endeavors are risky and expensive at first, but are very important to the long-run competitiveness of industries in an increasingly international marketplace.

Due to the lower profitability, 'gross fixed capital formation' as a percentage of gross domestic product was lower in the US than in most other large industrial nations in the 1970s and 1980s - the US ratio averaged 18 percent compared to 23 percent in West Germany and 32 percent in Japan. ${ }^{39}$ Also, less economy-wide capital formation in the US during this time period allowed less improvement in industry competitiveness, as measured by output per worker (productivity).

Despite popular sentiment at the time in the 1980s, much of the increase in US corporate debt was desirable, because US capital costs could be lowered at least as much as the gross return on capital. Increased profitability on capital occurred, more investment in US industry was justified, and worker productivity improved, ceteris paribus. There was less chance that US corporations had the liquidity problems and low stock market values which invited hostile takeovers and disrupted long-run strategies. Instead, the corporations' bankers had more control over the corporation, and a greater self-interest in seeing that the corporation was successful in the long run. As acknowledged by Benjamin Friedman (in Feldstein, 1991, p. 20): 
Some observers have argued that most of the [US] substitution of debt for equity in recent years has occurred in the context of reorganizations that are likely to promote business efficiency and hence provide the higher earnings with which to service the added debt; also, that these transactions are explicitly designed to minimize conventional bankruptcy problems in the event that the anticipated higher earnings do not materialize. Others have pointed out that even after the refinancings of the 1980s, US corporations on average remain much less highly leveraged than their counterparts abroad.

Also, the globalization of financial markets in the 1980s provided the greatest benefits to the borrowers who had historically paid the highest interest rates. In the 1970s and early 1980s, before the globalization of financial markets, it was the US interest rates which were the highest. Therefore, it was US borrowers, especially those who creatively took advantage of the new international opportunities, who found the greatest savings with globalization. American corporations realized the benefits of increased borrowing, especially from the new international markets: Eurobonds issued by American corporations grew from $\$ 7$ billion in all of 1983 to $\$ 35.1$ billion in only the first ten months of $1986 .{ }^{40}$

By 1990, the globalization of debt and equity markets had already led to similar debt-equity ratios between the US, Japan, Germany, and others. Within the more commonly shared financial environment, corporations were choosing more similar financial strategies. For example, in 1990 the average debt-equity ratio of companies listed on the Tokyo stock exchange was approximately equal to the average debt-equity ratio of all US companies. ${ }^{41}$ Computing this ratio was extremely problematic because many newer financial instruments have both debt and equity characteristics, but it is likely that average US and Japanese corporations had approximately equal debt to equity ratios of 50 percent by 1990 .

With reference to the 1972-82 statistics presented above, Japanese companies thus reduced their debt levels in the 1982-90 period just as significantly as US companies increased their debt levels until corporate debt burdens were approximately equal in the two countries. Rather than seeing increased US corporate debt in the 1980s as a worrisome development originating in the US, therefore, it seems better to view this increased debt as a natural and healthy process of convergence or globalization. US, Japanese, and other corporations settled upon similar financial strategies in their new commonly shared financial markets. ${ }^{42}$ Initially, more attractive takeover targets were found in the equity-biased US capital stock, that is, until the late 1980s when globalization had brought international debtequity ratios closer together, and when financial markets became more similarly regulated and accessible. 


\section{B. International Price/Earnings Ratios Converge}

A natural process of convergence or globalization also occurred in the 1980s with international price/earnings ratios of corporate stock.

Different investors are willing to pay different stock prices for the ownership of corporate assets, depending upon expectations about the size and riskiness of future dividends and other cash pay-outs; preferences for having more cash in the present versus the future; availability of cash; and the availability of alternative investments. For example, in the Japanese stock market in the 1980s, investors were willing to pay an average of 50 dollars for corporate stock for every one dollar of current annual earnings generated by the stock, that is, a price/earnings ratio of 50. For Nippon Telephone and Telegraph, which had a total stock market value of \$320 billion on 31 March 1987 (more than the entire West German stock market), investors paid a remarkably high price/earnings ratio of 261.7.43

In the US stock market, investors in the 1980s were willing to purchase stock at an average price/earnings ratio of 15 , less than one-third of the Japanese stock market ratio, indicating a combination of the following structural conditions, labeled (1)-(5):

1. Future earnings and therefore cash pay-outs were not expected to be as high on US corporate stock compared to Japanese corporate stock.

2. Investors as a group felt that the dollar was likely to lose some of its exchange value relative to the yen, and they had not fully hedged away this currency risk.

3. In Japan investors were willing to pay a higher price and commit more savings for the expectation of future income compared to the more consumer-oriented US. Also, savings had been given more favorable tax treatment in Japan than in the US.

4. The Japanese tendency to retain earnings within the corporation rather than pay it out as dividends, and other institutional differences meant that a significant amount of Japanese earnings was hidden from the statistics.

5. There was more cash 'bottled-up' in the less deregulated Japanese financial markets, and there were fewer attractive alternatives to stock ownership compared to the US, such as home ownership.

In the 1980s, structural conditions (1)-(5) maintained the average prices of Japanese corporate assets at levels more than three times higher than US corporate assets, relative to the current income generated by those assets. These structural impediments, which maintained separate institutional and 
behavioral identities for the world's two largest stock markets, became less significant as financial globalization progressed, however. Consequently, there was a trend toward more similarly priced corporate assets in the US and Japan.

Structural condition (1) became less significant with the increased participation in joint ventures and overseas production by US and Japanese firms, the dual-listing of corporate stock in both exchanges, the recovery of US companies, such as those in automobiles, from exceptional Japanese competition of the early 1980s, the maturation of the Japanese economic miracle, the increased use of debt-financing in the US, and the massive net inflow of foreign funds into the US beginning in the 1980s which lowered interest rates and the cost of capital in the US while increasing them in capital-exporting Japan.

Condition (2) became less significant with the widely perceived bottoming-out in the decline in foreign exchange value of the dollar in the late 1980s, and with the rapid development of futures markets where foreign exchange risk can be hedged as per covered IRP discussed earlier. Condition (3) became less significant with the removal of various tax incentives to save within Japan since 1986, and as the Japanese economy became more consumer- and leisure-driven. Condition (4), which is more a statistical oddity rather than an economic condition, became less significant with the more standardized accounting techniques used by more internationalized (especially Japanese) corporations. And, condition (5) became less significant with the rapid deregulation and integration of the US and Japanese financial markets and increased learning, especially by Japanese investors, about foreign opportunities.

As these structural differences between the world's two largest stock markets began to lose their importance in the 1980s, perhaps especially as (5) became less significant, it was inevitable that Japanese investors began to purchase a lot of US stocks. In effect, the reasons for maintaining higher prices for corporate assets in Japan relative to current corporate earnings began to lose their importance, and the lower US price/earnings ratios became quite attractive to Japanese investors.

Thus, the reduced importance of structural conditions (1)-(5) explains the Japanese 'buying of America' in the 1980s. However, the removal of structural differences and impediments between financial markets everywhere encouraged a more general foreign buying of America. For example, German purchases of US business assets in the 1980s rivaled purchases by the Japanese, but neither country maintained as large a historic claim on US assets as Britain or the Netherlands. Both Japan and Germany made major long-term capital investments into the US in the 1980s. However, 'the channels from Japan to the United States are more direct than those 
from Germany to the United States', which might explain some of the greater attention paid to the Japanese purchases at the time.

Structural integration of stock markets began to encourage the rapid foreign buying of American business assets in the mid-1980s. For example, foreign investors purchased $\$ 5$ billion of publicly owned US corporate stock in 1985, \$25 billion in 1986, and \$30 billion in 1987. The world stock market crash of 1987 slowed this upward trend only temporarily. By 1989, 11.1 percent or $\$ 500$ billion of America's $\$ 4,550$ billion total business assets were foreign owned.

As structural impediments between the major equity markets continued to erode, and as portfolios were appropriately reallocated, price/ earnings ratios converged toward something like 20:1. Adjusting for differences in institutions and accounting rules which remained, a 1992 study found that 'true' price/earnings ratios for Japan, the US, Britain, France, and Germany were, respectively, 22.1, 26.5, 19.6, 14.5 and 19.1. ${ }^{44}$ Compared to stock market levels of the late 1980s, and assuming reasonably constant growth rates of corporate earnings in the US and Japan, this convergence required a doubling of US stock market prices and a 50 percent decline in Japanese stock market prices from the late 1980 s to 1992 - which was exactly what happened. The Japanese financial crisis that emerged in 1989 as part of this adjustment is discussed in Chapter 3.

\section{SAVER AND DISSAVER COUNTRIES}

Unexpectedly large trade and investment imbalances developed between the US, Japan, and others during the 1980s, which have continued. From 1984 to the mid-1990s, the US had a trade deficit averaging more than $\$ 100$ billion per year, and as a necessary counterbalance the US received a net inflow of foreign investment of more than $\$ 100$ billion per year-both of which increased in the wake of the 1997 Asian crisis to approximately $\$ 200$ billion per year and then further to a maximum of $\$ 800$ billion in 2006 at the peak of 'the long boom' (Chapter 4) before beginning to decline in 2007 and 2008 following the recent crisis.

Despite intense focus on this topic by the economics profession, there has been disagreement over the international adjustment mechanisms and key variables that link trade and investment flows. For example, the general consensus of Paul Krugman and others in Bergsten (1991) seemed to be that imbalances in US trade and finance could be appropriately reduced by movements in currency exchange rates and government policy responses such as protectionism: 
The need to reassess became especially acute in the late 1980s as widespread disappointment emerged over the continuation of sizable imbalances despite large changes in exchange rates and other policy measures aimed at reducing the imbalances. (p. xi)

[However] once we clean up the data, it seems possible to argue that trade flows have responded to exchange rates in just about the way that an economist who had avoided listening to any new ideas [since 1970] ... would have expected. (p. 11)

Yet Robert Mundell, among others, argued that currency realignments and trade barriers play no useful role in improving trade balances and may even be harmful in the US case:

The claim that [favorable consequences] will follow from depreciation is sheer quackery. It is closer to the truth to say that a policy of appreciating the yen and the European currencies relative to the dollar will cause deflation abroad, inflation at home, a larger dollar deficit, and vast equity sales to foreign investors. Ownership of factories, technology, and real assets will be exported to finance an even larger trade deficit without there being much, if any, real expansion in exports or reduction in the dollar value of imports. US assets will be sold abroad at bargain-basement prices. If the American dog gets fed better, it will be by eating its own tail. (Mundell, 1987)

The Mundell side has been taken by those, for example from the Japanese perspective during the 1980s-90s, who argue that only the US can improve its trade deficit, when it saves and invests more and improves its productivity:

The fundamental causes of the dollar's depreciation [over 1985-95] are the US budget deficit and an unfavorable balance of payments which shows no sign of improving. Only the US itself can recover the dollar's status as an international key currency. Therefore, in the long run, decreasing the budget deficit and enhancing productivity are vital steps. (Wakasugi, 1987)

Taking issue with each of these quotes, this section argues that the financial market globalization, IRP, and FSP processes as discussed in the previous section are new driving forces responsible for the large trade and investment imbalances that began in the 1980s and 1990s. More autonomous and controlling international financial flows are often causing changes in trade and economic growth, rather than vice versa. Proper consideration of the structural changes from this chapter leads to some new conclusions about the international adjustment mechanisms and key variables that affect trade and investment flows. Increasingly, the nation should not be seen as a self-sufficient or 'balanced' economic region. 
As discussed in the previous section, more lenders have been put in contact with more borrowers by financial market deregulation and the information revolution. Larger sums of money have been moving more quickly and profitably around the world. Those who tend to spend more than their current income, dissavers, have been more quickly accommodated with an appropriate interest rate by those who tend to spend less than their current income, savers. Inherent tendencies, whether toward dissaving or saving, have thus been encouraged for individuals, firms, and countries.

The establishment of saver and dissaver countries was especially noticeable during the initial 'boom years' for international financial markets in the early and mid-1980s. The biggest new saver country was Japan, where individuals were saving more than 15 percent of their disposable personal income. In addition to accommodating the borrowing needs of its business and government sectors, personal savings allowed Japan to increase its net long-term lending to the global financial markets from less than $\$ 20$ billion in 1983 to $\$ 50$ billion in 1984 to $\$ 62$ billion in $1985 .{ }^{45}$

The biggest new dissaver country was the US, where individuals reduced their personal savings rates from 9 percent in the early 1980s to an average of only 4 to 5 percent after the mid-1980s. In late 1998, US savings rates actually reached zero. Over the 1980s and into the 1990s, European personal savings rates were midway between the Japanese and US rates in the 7-13 percent range. (Chapter 4 elaborates the quite different environment for savings since the recent economic crisis, whereby US household savings rates have now risen back to 5 percent and Japanese rates are instead approaching zero.)

No matter how US personal savings was measured, beginning in the early 1980s it was not nearly enough to meet the borrowing needs of the US business and government sectors. For example, without the benefit of foreign lending and investment in 1985, US personal savings would have provided only $\$ 58$ billion for the business sector after financing the $\$ 200$ billion federal budget deficit — not enough to keep the economy running at its 1985 output rate of $\$ 4$ trillion.

It was the increase in the net inflow of foreign lending and investment into the US from $\$ 9$ billion in 1982 to $\$ 118$ billion in 1985 which allowed the US business sector to maintain a high level of output and employment in the mid-1980s, while at the same time the US government was running record deficits. Since the mid-1980s, the US economy has continued to dissave or 'absorb' a large share of the rest of the world's savings. As discussed throughout the remainder of the book, this continuing absorption and use of world savings in the US economy has been one of the most significant structural changes associated with the new global economy, and 
it affects just about everything including economic growth, government budgets, trade patterns and various financial crises and recession. For example, as discussed in Chapter 3, the 1997 Asian financial crisis and the 1997 unexpectedly strong US economy were (not coincidentally) associated with a sudden jump in net financial flows out of Asia and into the US, where the net inflows exceeded $\$ 200$ billion per year.

Why, in the 1980s, was the US personal savings rate exceptionally low compared to, for instance, Japan? The generally accepted reasons are as follows.

1. Earnings on US savings (interest and dividends) are taxed, whereas interest expense on borrowing (for home ownership and businessrelated purposes) is tax deductible. The incentive is therefore to borrow and spend, not to save. In Japan, most savings have been completely exempt from taxes, that is, until 1 April 1988, when many of 'the world's largest tax loopholes' were closed. ${ }^{46}$

2. The US baby boom, that is, people born from 1946 to 1958, were in their key spending years for housing, cars, and so on. The savings years and the earnings power were just arriving in the 1980s as the baby boomers entered their fifties and sixties.

3. The US social security system covers a broader base of people than does Japan's system, which reduces the anxiety to save. A more developed corporate pension plan in the US also reduces concern for the future. The Japanese must generally save as individuals for their retirement. Social security contributions in the US, the largest income security program, ${ }^{47}$ are not measured as personal savings; thus the commonly reported US personal savings rate understates the true level of savings.

4. Americans are home owners compared to the Japanese. By spending money on home ownership, Americans are building up equity and financial security for their future, but this 'residential investment' reduces rather than adds to the supply of loanable funds. The Japanese must save more money for future rental of housing, including furniture and appliances because they do not as commonly own these things. Also, when the Japanese buy a home they must save for a more substantial down-payment.

5. In the 1980s many credit accounts in Japan worked like the US system of decades ago-little black books at the corner store or post office. The credit card revolution in the US encouraged borrowing by making it easier and more socially acceptable. In 1980, the average unpaid balance per American cardholder was \$375, in 1986 approximately $\$ 940$, and by 1990 it exceeded $\$ 2,000$. 
6. A larger share of farm income has historically been saved in the US compared to other sources of income, and farm income has declined from 4 percent of all personal income in 1973 to less than 1 percent of all personal income after 1990.

7. An additional, rarely mentioned explanation of the low US savings rate, which applied especially since the 1980s, is that the new global economy has provided the US with new, low interest rate borrowing opportunities. The US savings rate declined from over 8 percent in the early 1980 s to 4 percent in the mid-1980s, which was the same period of time during which the US financial markets were integrated with the financial markets of Japan and other lower interest rate, saver countries. US interest rates declined by approximately 4 percentage points from the early 1980s to the mid-1980s, largely due to the inflow of newly deregulated profit-seeking foreign funds. Consequently, the US incentive to save was reduced, and the incentive to borrow and spend was increased, both of which reduced the US personal savings rate.

Most likely, it was (7), the globalization of financial markets, which reduced the US personal savings rate to post-World War II lows by the mid-1980s. Most of the other (1)-(6) commonly accepted reasons for the low US savings rate were in place in the 1970s as well as the 1980s, and it is unlikely that they caused the dramatic drop in the US savings rate right after 1981. But many of the financial market deregulations mentioned in this chapter occurred right at the beginning of the 1980s, including UK and Japanese liberalization of foreign capital controls. Profit-seeking foreign capital, which allowed for lower US interest rates and lower US savings, was also attracted to the US by the big Reagan tax cuts of 1981-83 which enhanced returns on US investment. The Reagan tax cuts also led to the large federal budget deficits and government dissaving and attractive returns on Treasury securities (see Chapter 2, Section VI).

Removal of the US withholding tax on interest payments to foreigners in 1984 further encouraged foreign purchases of US Treasuries in 1984-85. There was no increase in foreign purchases of US corporate bonds in 1984-85 due to removal of the withholding tax, because corporate bonds had been available in the Eurodollar market for some time without being subject to withholding.

Lower US interest rates and lower US savings after 1981 were also allowed when US banks reduced their exposure to LDC debt and repatriated funds back to the US. Virtually all new private loans to the LDCs stopped when the world debt crisis hit in 1982.

The low US personal savings rate together with record federal government 
budget deficits caused the US to become a 'debtor' country in 1985; the first time since 1914. In just four years, from 1982 to 1986, the US reversed its position as the world's biggest 'creditor' nation and became the world's biggest debtor nation. Japan became the biggest creditor nation. By the mid-1990s, Japan had accumulated $\$ 800$ billion net ownership of foreign assets, and the US found that foreign ownership of US-based assets exceeded US ownership of foreign-based assets by more than $\$ 1$ trillion.

Commonly reported as the annual increase in US 'debt' to foreign countries, actually much of it indicated that foreigners were purchasing more US real estate, business assets, and other property compared to US claims on foreign property. The Commerce Department estimated that more than 10 percent of the $\$ 4.5$ trillion in US business assets were foreign owned by $1988,1.3$ percent of the $\$ 7.5$ trillion in US real estate, and 5 percent of the $\$ 8.4$ trillion in debt owed by all US sources.

The author's position is that US federal budgets with deficits over $\$ 150$ billion would not have been passed between the mid-1980s and the mid-1990s without the ready availability of foreign savings. A (hypothetically) financially self-sufficient US economy in this period with $\$ 100-\$ 150$ billion of household savings 'left over' for the business sector assuming a $\$ 150$ billion federal deficit would have been severely recessionary.

National policymakers, whose electiveness and careers frequently require them to maintain economic growth, thus began encouraging the inflow of foreign funds in the 1980s. In a surprising turnaround from previous speeches, US President Reagan argued on 11 January 1987 that 'inflows of foreign capital are not necessarily a sign of an economy's weakness' ${ }^{48}$ Comparing the national debt to California's external debt to other states, Reagan said 'does this augur bad days ahead for California? On the contrary, one might argue it's a sign of strength'.

\section{NOTES}

1. 'Capital Markets Survey', The Economist, 21 July 1990, p. 7.

2. 'Central Banks Issue Warning on Trading', The New York Times, 28 March 1996, C1.

3. 'Japanese Firms Make Controversial Bid in the US Government Securities Market', The Wall Street Journal, 7 January 1986, p. 32.

4. 'The Globalization of the Industrialized Economies', Barron's, 4 May 1987, p. 45.

5. 'New Guidelines for Derivatives Are Delayed', The Wall Street Journal, 9 May 1997, p. A4.

6. 'Harbours of Resentment', Financial Times, 1 December 2008, p. 11.

7. 'Down and Out on Trillionaire's Row', Financial Times, 11 October 1993, p. 14.

8. 'Storm Survivors', The Economist, 16 February 2013, http://www.economist.com/news/ special-report/21571549-offshore-financial-centres-have-taken-battering-recently-theyhave-shown-remarkable.

9. 'Tax Havens, the Mission \$20 Trillion', The Economist, 16 February 2013, http://www. 
economist.com/news/leaders/21571873-how-stop-companies-and-people-dodging-taxdelaware-well-grand-cayman-missing-20/print.

10. 'Banks and Information Technology', The Economist, 5 December 2009, p. 83.

11. 'The New American Challenge', The Wall Street Journal, 3 November 1986.

12. 'The Global Money Market', The New York Times, 4 May 1986, p. 10 F.

13. 'Your Future in Telecommunications', Business Week Careers, November 1986, p. 59.

14. Ibid.

15. 'Business Bulletin', The Wall Street Journal, 10 March 1988, p. 1.

16. 'Business Goes Body Shopping', Newsweek, 10 July 1989, pp. 46-7.

17. 'Foreign Issues Flood London OTC Trade', The Wall Street Journal, 18 April 1986, p. 22.

18. Data from Spencer Nilson and The Nilson Report, Oxnard, California, mid-1996.

19. 'Central Banks and Digital Currencies: Redistributed Ledger', The Economist, 19 March 2016, p. 75 .

20. This case study, as it affected the US balance of payments, is analyzed in Cooper (1965).

21. 'Three Big Japanese Firms Enter Ranks of Primary Dealers Despite Opposition', The Wall Street Journal, 12 December 1986, p. D-1.

22. 'Stakes High for Britain's Financial Firms in Freer Markets', The New York Times, 6 October 1986, p. 34.

23. 'London's Exchange Braces for Big Bang Set to Occur Monday', The Wall Street Journal, 24 October 1986, p. 1.

24. 'Common Market Seeks New Rules on Limiting Exposure of Lenders', The Wall Street Journal, 1 December 1986.

25. 'Ontario Will Open Securities Industry to Foreigners, Domestic Finance Firms', The Wall Street Journal, 5 December 1986, p. 38.

26. 'Global Finance: Tale of 3 Cities', The New York Times, 31 October 1986.

27. 'French Denationalization Lures US Firms', The Wall Street Journal, 24 October 1986, p. 28.

28. 'China's Embryonic Stock Market Expands', The Wall Street Journal, 12 November 1986, p. 38.

29. 'School at China's People's Bank Trains New Generation of Financial Whiz Kids', The Wall Street Journal, 18 November 1986, p. 39.

30. 'China's Initial Offering of Eurodollar Bonds Is Set', The Wall Street Journal, 21 August 1987, p. 21.

31. 'Confronting the Soviet Financial Offensive', The Wall Street Journal, 22 March 1988, p. 34 .

32. 'East Europe's Sale of the Century', The New York Times, 22 May 1990, p. C1.

33. Source: Bank for International Settlements, based on information from banks in the Bank for International Settlements reporting area, comprising 18 industrialized countries and seven offshore banking centers.

34. 'Capital Unchecked', The Economist, 19 October 1985.

35. 'US Business Should Take On More Debt', The Wall Street Journal, 1 December 1986.

36. Ibid.

37. Ibid.

38. 'Japan's Tax Policy-A System that Works', San Francisco Chronicle, 21 November 1985.

39. Source: IMF.

40. 'Finance Officers' Wider Role', The New York Times, 20 October 1986.

41. 'Escape from Debt', The Economist, 21 July 1990, p. 84.

42. The replacement of equity with healthy debt-financing in the US did seem to minimize the disruptive, uninsured, junk-bond financing techniques of corporate raiders. In 1990, shortly after the indictment of its junk-bond king Michael Milken, Drexel Burnham Lambert declared bankruptcy. Drexel Burnham Lambert had accounted for 40 percent 
(\$10 billion) of junk-bond trading in 1989, and in the late 1990s this market had smaller volumes than its levels of the late 1980s.

43. 'Soaring Shares of Japan's NTT Worry Analysts, Delight Holders', The Wall Street Journal, 24 April 1987, p. 17.

44. 'All the World's a Ratio', The Economist, 22 February 1992, p. 72.

45. 'Japan's Foreign Fundings', The New York Times, 13 April 1986.

46. 'Japan to End One of the World's Largest Tax Loopholes', The Wall Street Journal, 23 March 1988, p. 22.

47. In 1986, according to the US Census Bureau, the value of US poverty programs was equal to $\$ 48.2$ billion, while social security benefits amounted to $\$ 196.1$ billion ('Benefits Beat Taxes as Income Equalizer', The Wall Street Journal, 28 December 1988, p. A2).

48. 'Reagan Says October Crash Resulted from Markets, Not Deficits and Dollar', The Wall Street Journal, 12 January 1988, p. 3. 